\title{
eLearning -15 Years at Czech Universities
}

\author{
Petra Poulova, Miloslava Cerna, Ivana Simonova \\ Faculty of Informatics and Management \\ University of Hradec Králové \\ Hradec Králové, Czech Republic
}

\begin{abstract}
At the beginning of this millennium the European Commission announced eLearning to be a strategic plan for developing new trends in gradual and lifelong education. Analogous to other European countries also in the Czech Republic strong emphasis was put on education, particularly on improving competences in the field of ICT and foreign languages. Adequate changes reflecting these global tendencies in the last decade were run on all levels of the Czech educational system from the primary to the tertiary level, including the lifelong education. These tendencies are strongly reflected in engineering education. Despite the starting problems in the last decade, eLearning has become a standard within the tertiary education. The eLearning forms of instruction at universities can be used in both gradual study programmes and lifelong education. eLearning can be applied in the distance study programmes, in the combined (part-time) form of instruction or supporting present lessons (blended learning).
\end{abstract}

Keywords- eLearning, eLearning polices, infrastructure, Learning Management System, research, university education

\section{INTRODUCTION}

The strategy of European Union in the field of education since the end of the 20th century has been characterized by the emphasis on the development of key competences, mainly in the field of the information and communication technologies (ICT) and foreign languages. This strategy has been defined by several important documents prepared by European Commission, e.g. "Growth, competitiveness, and employment. The challenges and ways forward into the 21 st century" [1]; "White Paper on Education and Training - Teaching and Learning - Towards the Learning Society" [2]; "The eLearning Action Plan: Designing tomorrow's education" [3]; etc.

Similarly to other European countries the Czech educational system also underwent substantial changes in the last decades. The ICT-supported distance form of education appeared in the Czech educational system after 1990. The combined and distance forms of education are often the only way for busy people how to reach the necessary qualification. High motivation and personal maturity of university applicants enable to use higher share of self-study supported by information and communication technologies. These approaches quickly penetrate the lifelong education but can be easily applied in the present form of study at educational institutions of all levels. [4],[5]

Information technology, particularly the computer support in education has been widely and frequently applied, researched and evaluated for last two decades. During quite a short fifteen-year history the term of eLearning has not been defined exactly. It depends on the author's view which features are emphasized. It resulted from putting together the word learning and e-prefix, similarly to other terms relating to eLearning, e.g. in e-mailing, e-banking, e-commerce, ebusiness, e-book. Putting the e-prefix and word learning together, the term arises which means a modern way of education using computer technology, computer networks and appropriate applications, i.e. it enables running such a process of education where information and communication technologies are implemented.

eLearning has been changing under the developing conditions, so does its definition. Various authors provide different terminology and definitions. Differentiated views are caused by a wide range of the field and influenced by the environment in which and how it is applied. [6]

Some authors emphasize a technological approach to eLearning. They understand it as a tool for designing, updating, distribution and evaluation of the process of instruction, knowledge management run by net technologies and computers with appropriate hardware and software equipment. Other authors emphasize multimediality of eLearning, and another approach emphasizes eLearning in computer networks and on the Internet.

The pedagogic (didactic) approach provides another view. eLearning is understood as such a way of instruction which uses information and communication technologies to managing the whole process, designing courses, distributing study content, communication between students, teachers. [7]

As it is obvious from the above mentioned definitions, eLearning is approached from two main directions. First, it is an educational process which uses information and communication technologies. Second, it is understood as a set of technological tools applied in education. In the wide context, eLearning is the educational process supported by information and communication technologies. Computer applications integrate single elements, combine explanations in the text form with animations, simulations, graphics, diagrams, audio and video recordings, electronic tests. Students can choose the way which suits best their individual preferences. [8] eLearning includes not only educational systems available on the computer net but also educational software on portable media (CDs, DVDs). 
Last but not least, Logan defines eLearning as follows: "The " $e$ " doesn't stand for electronic. Better to think of the " $e$ " as evolving, or everywhere, or enhanced or extended ... and don't forget effective".

\section{ELEARNING AT CZECH UNIVERSITIES}

The eLearning forms of instruction at universities can be used in both gradual study programmes and lifelong education. eLearning can be applied in the distance study programmes, in the part-time study programmes or to support present lessons (blended learning).

In 2001 the European Commission announced eLearning to be a strategic plan of developing new trends in gradual and lifelong education. The strategic objective of this action was the integration of European structural funds and European Bank sources to further development and support of educational activities. [3] Similar to this, in the Czech Republic strong emphasis has been put on education and improving competences in the field of ICT and foreign languages since the beginning of this century.

These decisions caused substantial changes in the educational concept. A wide range of agreement and disagreement with new educational approaches could be seen both across the whole system and insight the single institutions. [7]

The process of eLearning implementation could be structured into three basic steps: [9]

First, getting new hardware, software and other class equipment was essential. In real life new computers and programmes were bought, classrooms equipped with data projectors and special computer furniture (tables, chairs) which are user-friendly and do not damage health after long hours of sitting in front of the computer.

Second, forming general media competence followed. It means that all possible participants of the process had to learn how to work with computers and become computer literate, which covers academic, technical and administrative staff of the faculty, and students. Current understanding of what the expression media competence really means is explained from the point of basic computer literacy, which covers the use of computers and information and communication technologies. Knowledge management, i.e. the strategy how to work with information, gain and process it, apply in professional work, is closely related to it. This competence was formed by studying and testing for ECDL Certificate at most Czech universities, and both teachers and students participated in the courses. They were often run in the distance way, so participants received additional experience, i.e. the student's role.

Third, applying the general computer literacy in education which is the most difficult and demanding part, crucial for the process of education. It covers didactic training aimed at both teachers and students so that they know how to teach and study being supported or managed by ICT.

At the very beginning of this process, Step Zero was usually introduced at several universities which meant e.g. presenting study materials in shared directories, using e-mail for communication between teachers and students, creating university web pages, editing electronic journals etc. None of the mentioned tools belonged to common services at 1990s. But over few years quite static shared directories did not meet new requirements and were replaced by web pages supporting instruction of single subjects, then piloting of a learning management system started, either to be bought, or another system designed according to university requirements . [10]

\section{THE PROCESS OF ELEARNING IMPLEMENTATION AT CZECH UNIVERSITIES}

In 2009 - 2012 academic years the research team of the University of Hradec Králové solved several projects dealing with eLearning. One of the partial projects focused on the process of its implementation at Czech universities. [11] [12] , [13]

In 2012 twenty-six public universities have been accredited in the Czech Republic, two state colleges and more than 45 private (non-state) ones. Although the number of private colleges is twice higher than state universities, only few per cent of students are enrolled. Number of students and short tradition are the main reasons why only public universities were included in the research. Annual reports of Czech public universities from 1999 to 2012 were the main source of information. Twenty-six universities were included in the research:

- Academy of Art, Architecture and Design, Prague (VŠUP),

- Academy of Performing Arts, Prague (AMU),

- Academy of Fine Arts, Prague (AVU),

- Brno University of Technology (VUT),

- Charles University, Prague (UK),

- College of Polytechnics, Jihlava (VŠPJI),

- College of Technology and Economics, České Budějovice (VŠTE),

- Czech Technical University, Prague (ČVUT),

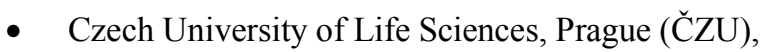

- Institute of Chemical Technology, Prague (VŠCHT),

- Jan Evangelista Purkyně University, Ústí nad Labem (UJEP),

- Janáček Academy of Performing Arts, Brno (JAMU),

- Masaryk University, Brno (MUNI),

- Mendel University, Brno (MZLU),

- Palacký University, Olomouc (UPOL),

- Silesian University, Opava (SLU),

- Technical University of Liberec (TU),

- Tomas Bata University, Zlín (UTB), 
- University of Economics, Prague (VŠE),

- University of Hradec Králové (UHK),

- University of Ostrava (OSU),

- University of Pardubice (UPCE),

- University of South Bohemia, České Budějovice (JCU),

- University of Veterinary and Pharmaceutical Sciences, Brno (VFU),

- University of West Bohemia, Plzeň (ZČU),

- VŠB-Technical University of Ostrava (VŠB-TU).

College of Technology and Economics, Jihlava, was established in 2006, and that is why five-year data are provided only. The research sample contained annual reports of single universities published in 1999 - 2012. If universities published annual reports of single faculties, colleges etc. as well, these were not included in the research.

In total, more than 250 annual reports were included in the research. In some cases there were not all annual reports available, several ones were missing.

Information on eLearning was searched, both in the form of single chapters and in the data mentioned in the text. Most frequently the topic of eLearning was included in the chapter on Information and communication technologies, which is an obligatory part of annual report structure given by the Ministry of Education, Youth and Sports. The collected data underwent the process of critical examination and evaluation from five points of view: [6]

- chronological development of eLearning implementation,

- academic staff education,

- eLearning centers,

- eLearning projects,

- $\quad$ Learning Management Systems (LMS).

\section{THE PROCESS OF ELEARNING IMPLEMENTATION IN ENGENEERING EDUCATION AT CZECH UNIVERSITIES}

Despite the engineering education is provided by most of Czech universities, only following eleven ones run substantial deal of it and were included in the research sample.

- Brno University of Technology (VUT),

- College of Polytechnics, Jihlava (VŠPJI),

- College of Technology and Economics, České Budějovice (VŠTE),

- Czech Technical University, Prague (ČVUT),

- Czech University of Life Sciences, Prague (ČZU),

- Institute of Chemical Technology, Prague (VŠCHT),
- Mendel University, Brno (MZLU),

- Technical University of Liberec (TU),

- University of Economics, Prague (VŠE),

- University of Pardubice (UPCE),

- VŠB-Technical University of Ostrava (VŠB-TU).

\section{A. Chronological development of eLearning implementation}

An electronic support of instruction first appeared in 1999 University of Ostrava annual report.

In 2000 eLearning emerged in three annual reports. The annual report of University of Hradec Králové, University of Ostrava and University of Economics, Prague. University of Economics described their eLearning project, they planned to design a course for academic staff on LMS WebCT and LearningSpace, One year later, in 2001, eLearning was mentioned in annual reports of these engineering educational institutions:

Czech Technical University, Prague, described

- ICT integration into educational parts of their longterm plan,

- eLearning pilot projects,

- $\quad$ support to designing five eLearning courses.

\section{VŠB-Technical University of Ostrava}

- $\quad$ prepared study materials for combined (part-time) and present form of study on university website.

University of Economics, Prague,

- $\quad$ prepared the distance form of master study programme in eLearning form for accreditation,

- $\quad$ organized training for academic staff,

- $\quad$ put a video server into operation.

Institute of Chemical Technology, Prague

- gradually built a virtual library of electronic study materials on university websites.

The Mendel University, Brno, states no eLearning activities in the institution. Other universities do not mention eLearning at all.

In 2002 the number of engineering educational institutions using eLearning substantially increased again. Czech University of Life Sciences, Prague, Technical University of Liberec, Mendel University, Brno, joined the eLearning community and made some references to eLearning in their annual reports.

Since 2003 eLearning has been mentioned in annual reports of most universities. 
College of Polytechnics, Jihlava, was established in 2004 as non-university public institution, and mentioned eLearning just in that year and College of Technology and Economics was established in 2006 a eLearning activities are first mentioned in this year. (see Figure 1)

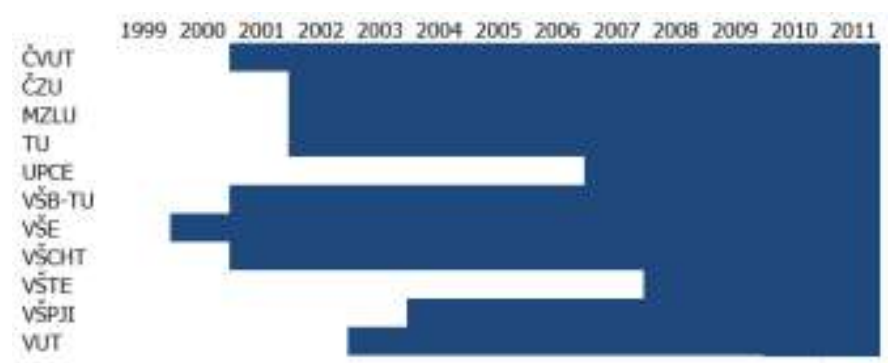

Fig. 1. eLearning in engineering education - chronological wiev

In most annual reports the comparison to previous years is provided. The applied hardware and software technologies, number of newly designed eLearning courses, increase in numbers of LMS users, projects dealing with eLearning and its implementation into strategic university documents are described there.

\section{B. Academic staff education}

As mentioned in the chapter eLearning at Czech universities, successful eLearning implementation takes paying attention to academic staff education in the field of new methods, both from the technical point of view, and pedagogy and didactics. This fact is crucial mainly in relation of engineering pedagogy because their academic staffs usually are excellent specialists in their field but hardly any education in pedagogy, as well as in didactics and branch didactics. In some cases they are limited by lack of knowledge and experience in using ICT in the process of instruction. That is why universities often present ways and results of process methodological support to eLearning in their annual reports.

The first mentioned training of academic staff in methodology of the distance education can be found in 2000 annual report of University of Economics, Prague, presenting the fact a course for teachers will be prepared focusing on methodology of designing an online subject supported by WebCT and LearningSpace technologies.

Two year later, in 2002, other three universities joined this forward-looking group - Czech Technical University, Prague, Czech University of Life Sciences, Prague, and VŠB-Technical University of Ostrava. This year a new important activity arose based on co-operation of three universities, University of Ostrava, Silesian University and VŠB-Technical University of Ostrava. Being situated geographically close, they put their sources together and prepared virtual training for academic staff in the field of eLearning (VirtUni seminars).

Most universities mentioned the academic staff training in methodology of the distance online and e-supported instruction. Several universities in their annual reports do not explicitly mention university staff education in the field of eLearning. (see Figure 2)

1999200020012002200320042005200620072008200920102011

ČVUT
ČZU
MZLU
TU
UPCE
VŠB-TU
VŠE
VŠCHT
VŠTE
VŠPJI
VUT

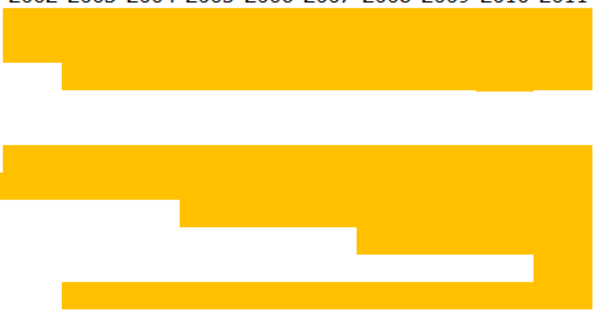

Fig. 2. eLearning in engineering education - academic staff education

University of Pardubice displayed on their web pages annual reports for last four years only, and they do not mention academic staff training in eLearning.

\section{C. eLearning centres}

At the beginning eLearning activities were supported by "enthusiasts", "eLearning pioneers" in single institutions, originating from their interests, having neither financial sources, nor authorization. During the years, when eLearning activities were spreading, most institutions included them into the strategies plans and budgets.

Several universities established special eLearning centers or departments, either as parts of IT centers, or working independently. Their names differ, e.g. Virtual Education Laboratory, Centre for Electronic (or technological) Support of Instruction, eLearning Department, etc.

These centers are responsible for functioning and availability of the hardware and software equipment, provide technical and methodological support to those designing new online courses, prepare and run training courses, in some cases they prepare own eLearning courses. The first universities dealing with engineering education which established the eLearning center were the Czech Technical University, Prague (Centre for instruction support in the Publishing House CVUT), Czech University of Life Sciences, Prague (Virtual education Laboratory) and University of Economics, Prague (Centre of eLearning Support) in 2002. One year later the Information Centre was established at the Mendel University, Brno. (Figure 3)

1999200020012002200320042005200620072008200920102011

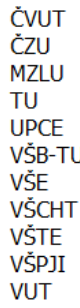

Fig. 3. eLearning in engineering education - university eLearning center 
These centers may help (if they work efficiently and appropriately) and support substantially the eLearning implementation at universities because they provide technical support, organize academic staff training and marketing support to eLearning activities. In several universities such centers work informally, not being established within the university structure.

\section{D. eLearning projects}

Financial funding and support of eLearning is another important field. Starting steps could be made thanks to enthusiastic pioneers requiring minimum expenses, but massive application must be systematically backed and supported. Expenses on hardware, software, Learning Management Systems and Content Management Systems, motivating eLearning course designers and tutors, academic staff training etc. cannot be considered without stable financial sources. So the starting phases are usually covered by project funding, then educational institutions started to share the expenses; only one technical university didn't use national or international eLearning projects as sources of financial support.

\section{E. Learning Management Systems}

The way how eLearning is applied in the instruction and what the efficiency of the process is substantially depends on the type of LMS which is used at the university. Ten of eleven institutions (91\%) mentioned the used type of LMS in the annual report. If the LMS is changed for several times, both academic staff and students must undergo training in new applications, and do not have conditions to use them efficiently.

At the very beginning of the process of eLearning implementation five institutions decided for a certain type, or started with two of three different types and later preferred another one. (Figure 4)

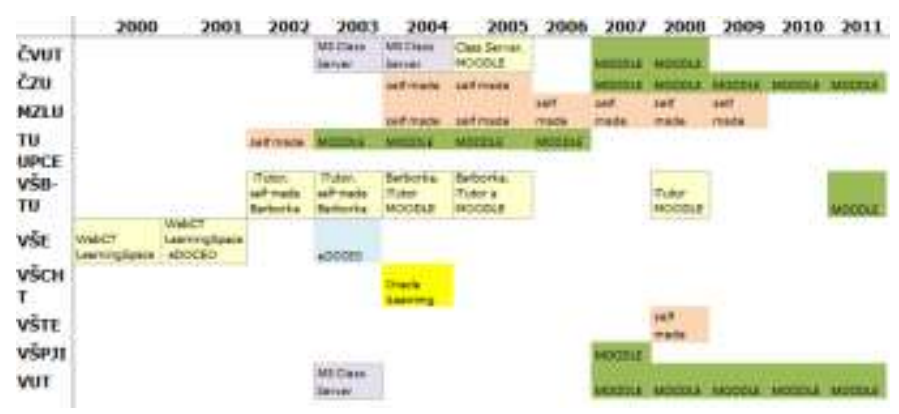

Fig. 4. eLearning in engineering education - LMS

Two of 11 engineering education institutions changed the type of LMS for three or more times (VŠB-Technical University of Ostrava, University of Economics, Prague). This fact could be causes by a long period of using the previous system, gaining negative experience, and the necessity to change it arose. In some institutions several eLearning activities ran simultaneously.
Four technical universities decided to design their own LMS (Czech University of Life Sciences, Prague, Mendel University, Technical University of Liberec, VSB-Technical University of Ostrava). In some cases they changed their previous decision and implemented a commercial or opensource system. If the institution has been using its own LMS, it usually is part of the whole university information system.

During the years LMS Moodle have become the most frequently used system. Currently, it is used by six technical universities, and other LMSs were also applied, e.g.:

- iTutor (one university),

- LearningSpace (one university),

- WebCT (one university),

- $\quad$ eDoceo (one university),

- MS Class Server (2 universities) and

- $\quad$ Oracle eLearning (one university).

\section{CONCLUSION}

In previous chapters of the paper basic facts on the process of eLearning implementation at Czech public universities focusing on engineering education were presented and summarized. The provided facts verify the statement eLearning had spread to most universities in the Czech Republic and had become standard, as it was in other developed educational systems. Both quantitative and qualitative development of eLearning courses can be observed in the last decade in the field of tertiary education, which can be seen e.g. on competitions of eLearning products which are held within national and international conferences.

The whole Middle- European Region underwent similar development in the field of university education in last several years, e.g. the situation in the Slovak Republic is similar. As the facts prove, in the last decade eLearning became a common approach to university education. Having spent the quantitative and qualitative development, further improvements in quality are expected by using modern technologies and/or social networks.

\section{ACKNOWLEDGEMENTS}

The paper is supported by the Excellence Project N. 2208.

\section{REFERENCES}

[1] European Commission. (1993). Growth, competitiveness, and employment. The challenges and ways forward into the 21 st century. Brussels: European Commission.

[2] European Commission. (1995). White Paper on Education and Training - Teaching and Learning - Towards the Learning Society. Brussel: European Commission.

[3] European_Commission. (2001). The eLearning Action Plan: Designing tomorrow's education. Brussel: European Commission.

[4] Turčáni, M., Bílek, M., Slabý, A. (2003). Prírodovedné vzdelávanie v informačnej spoločnosti. Nitra: FPV UKF. 
[5] Šimonová, I., Learning styles in foreign language instruction. In Interactive collaborative learning (ICL2011) - 11th International Conference Virtual University, VU'11, s. 595-601. ISBN 978-1-45771746-8.

[6] Poulová, P., Šabatová, M., Šimonová, I. ICT contribution to the process of e-learning implementation in the field of education. In Educational technologies (EDUTE'10) : proceedings of the 6th WSEAS/IASME international conference. Athens : World scientific and engineering academy and society, 2010, s. 157-161. ISBN 978-960-474-186-1.

[7] Šimonová, I., Poulová, P., Šabatová, M., Bílek, M., Maněnová, M. (2009). On Contribution of Modern Technologies Towards Developing Key Competences. Hradec Králové : M. Vognar.

[8] Šimonová, I., Bílek, M. The distance elearning. Comparative students'evaluation in 2005 - 2010: example of University of Hradec Kralove. In e-Learning : proceedings of the 9th European conference. Reading : Academic publishing, 2010, s. 571 - 577. ISBN 978-1906638-83-2.

[9] Poulová, P., Šimonová, I. (2009). The Ten-Year History of the Process of eLearning Implementation at Czech Universities. Problems of education in the 21 st century. vol. 2009, no. 17, pp. 159-167.
[10] Šimonová, I. Learners'experience in LMS in 2001 - 2010: case study. In Applied computer science : international conference. Athens : World scientific and engineering academy and society, 2010, s. 464-469. ISBN 978-960-474-225-7.

[11] Poulová, P., Šimonová, I. eLearning at Czech universities in 1999 2010. In e-Learning : proceedings of the 9th European conference. Reading : Academic publishing, 2010, s. 512 - 520. ISBN 978-1906638-83-2.

[12] Poulová, P., Šimonová, I. The traditional versus ICT-supported instruction within the tertiary education: comparative study. In i-Society 2011 : international conference : proceedings, London, UK, s. 321-326. ISBN 978-09564263-8-3.

[13] Šimonová, I., Poulová, P. Changes in Students'Attitudes towards Electronic Education in 2003 - 2010. In Latest trends on engineering education : 7th WSEAS international conference. Athens : World scientific and engineering academy and society, 2010, s. 343-348. ISBN 978-960-474-202-8.

[14] Annual repots of CVUT, CZU, MZLU, UPCE, TU, VUT, VSB-TU, VSE, VSPJI, VSCHT, VSTE $1998-2011$

\section{Creative Commons Attribution License 4.0 (Attribution 4.0 International, CC BY 4.0)}

This article is published under the terms of the Creative Commons Attribution License 4.0 https://creativecommons.org/licenses/by/4.0/deed.en_US 